\title{
„Mój przyjaciel z Haify powiedział, że gdy śni, nie śni o wrogu, lecz o sobie samym" Studia nad konfliktem palestyńsko-izraelskim jako wyzwanie dla studiów nad Zagładą
}

\author{
Pod wiatr! \\ A Ty wybuchniesz! Wybuchniesz na wszystkie strony... \\ i wtedy skończy się mowa pieśni, \\ a może znajdą pieśni w Tobie swoją ranę, swój ołów, swój obraz... \\ M. Darwish: To jej obraz... A on zabit się z miłości... ${ }^{1}$
}

\section{Wprowadzenie}

W artykule chciałabym odpowiedzieć na pytanie postawione przez Judith Butler: jak opowiadać historię ocalonych, by stała się ona drogą, która pomoże zapytać o przyszłość naszego własnego świata²? Pomocą służyć mi będzie wniosek, do jakiego dochodzi filozofka w szkicu Fiction and Solicitude. Ethics and the Conditions for Survival: „Naszym zadaniem jest zrozumieć ogólną kondycję ocalenia, dzięki której świat może stać się nie tylko znośny, ale wręcz możliwy do przetrwania. I zobaczyć możliwość zamieszkania w formach nieoczekiwanych

${ }^{1}$ M. Darwish: To jej obraz... A on zabił się z miłości... W: Pieśni gniewu i miłości. Wybór arabskiej poezji współczesnej. Oprac., przeł., wstęp K. SKARżYŃsKA-BocheńsKA. Warszawa 1990, s. 190.

${ }^{2}$ J. Butler: Fiction and Solicitude. Ethics and the Conditions for Survival. In: Probing the Ethics of Holocaust Culture. Eds. C. Fogu, W. Kansteiner, T. Presner. Cambridge, Massachusetts-London 2016, s. 388. Tłumaczenie moje - M.T. 
powiązań, przez języki, ze społecznością i poza nią, w aktach troski kierujących nas w stronę solidarności”’3.

Przykładami „ogólnej kondycji ocalenia” będą w tym tekście wiersze palestyńskiego poety Mahmuda Darwisha i film Jeana-Luca Godarda Nasza muzyka. Wybrałam je nie tylko dlatego, że podejmują tematykę konfliktu izraelsko-palestyńskiego, stanowiącego istotne tło moich rozważań. Dzięki poezji Darwisha i obrazowi Godarda można przeanalizować studia nad Zagładą w ich aspekcie literaturoznawczym, kulturoznawczym, historycznym, politycznym czy porównawczym w oderwaniu od ich wyjątkowości, jako pole badań otwartych na metodologiczną różnorodność i rodzące się lub trwające nieprzerwanie od lat spory polityczne. Warto zobaczyć, jak konflikt izraelsko-palestyński wymusza zmianę perspektywy badań nad Zagładą i pozwala do nich włączyć: (1) studia nad kruchością, (2) studia nad obrazami wojny oraz (3) postsyjonizm. Wyłonienie trzech nowych pól łączy się z intencją pokazania tekstów słabo obecnych w polskich opracowaniach zagadnienia, ma też na celu dyskusję metodologiczną wokół możliwości vulnerability studies i ich związków ze studiami nad Holokaustem.

Wiersze autora Palestyny jako metafory ukazały się po polsku po raz pierwszy w przekładzie Hanny Jankowskiej w antologii Pieśni gniewu i miłości. Wybór arabskiej poezji współczesnej z 1983 roku, ponownie wydanej w zmienionej wersji w 1999 roku. W 2004 roku miał premierę film Godarda, dystrybuowany w Polsce przez Media Service na płytach DVD. To ostatni jak dotąd w dorobku tego reżysera film fabularny. Jednym z jego bohaterów był właśnie Darwish, grający samego siebie. W 2010 roku Paweł Mościcki opublikował porywający esej na temat Historii kina ze wzmianką o Naszej muzyce ${ }^{4}$. Cztery lata później ukazało się polskie tłumaczenie książki $\mathrm{Na}$ rozdrożu. Żydowskość i krytyka syjonizmu Butler ze szkicem na temat relacji poetyckiej Edwarda Saida i Darwisha ${ }^{5}$. To bardzo niewiele jak na dzieła tych wybitnych osobowości twórczych. Można przyjąć, że za nieznajomością wspomnianych narracji kryje się poważniejszy problem - redukcjonistycznego spojrzenia na badania Zagłady w Polsce. Między innymi w monografii Moniki Bobako Islamofobia jako technologia władzy. Studium $z$ antropologii politycznej ów redukcjonizm został opisany jako niechęć do zestawiania i porównywania Holokaustu ze zbrodniami kolonialnymi ${ }^{6}$. W badaniach prowadzonych poza Polską „wyparcie historii kolonializmu ze zbiorowej pamięci postimperialnych społeczeństw zachodnich przejawia się także w oficjalnych dyskursach politycznych, w których zamiast prób wzięcia

3 Tamże.

${ }^{4}$ P. Mościcki: Godard. Pasaże. Kraków-Warszawa 2010, s. 304.

${ }^{5}$ J. Butler: Na rozdrożu. Żydowskość i krytyka syjonizmu. Przeł. M. Filipczuk. Warszawa 2014, s. 340-373.

${ }^{6}$ M. Вовако: Islamofobia jako technologia władzy. Studium z antropologii politycznej. Kraków 2017, s. 189. 
odpowiedzialności za kolonialne niesprawiedliwości pojawia się często nostalgiczna afirmacja imperialnej przeszłości”7.

Warto w tym krótkim wprowadzeniu przypomnieć jeszcze jedno stanowisko teoretyczne - Michaela Rothberga, autora Pamięci wielokierunkowej..., analizującego między innymi powiązania kina nowofalowego i francuskiej polityki lat 60. z Zagładą: „Fakt, że dziś Zagładę często przeciwstawia się globalnym historiom rasizmu, niewolnictwa i kolonializmu, stanowi przykład nieczystej walki polegającej na porównywaniu ofiar - jak ma to miejsce w niesławnym przemówieniu Muhammada i w wypowiedziach wielu »obrońców« wyjątkowości Zagłady - i stanowi element odmowy uznania wcześniejszych powiązań historii [...]. Jednak zwyczajnie nieuświadomiona historia wzajemnych powiązań, które charakteryzują okres dekolonizacji, trwa do dziś i ustanawia warunki możliwości zaistnienia współczesnego dyskursu. Zacietrzewienie wyczuwalne w tonie tak wielu dyskusji na temat rasy, ludobójstwa i pamięci - i dotyczące wszystkich stron sporu - wynika zatem, innymi słowy, poniekąd z retorycznej i kulturowej bliskości [podkreśl. - M.T.] pozornie przeciwstawnych tradycji upamiętniania"8.

Taką retoryczno-kulturową bliskość wykazują między innymi niektóre narracje o Zagładzie i współczesne opowieści o Wołyniu. Spotkamy ją również choć z innych przyczyn - w Małej Zagładzie Anny Janko. Porównawcze studia nad Holokaustem i kolonializmem w Polsce mają więc przed sobą wiele zadań. Zestawienia poezji Darwisha z Naszą muzyką dokonuję na odmiennej zasadzie zupełnego niepodobieństwa: i to zarówno pomiędzy filmem i wierszami, jak i między filmem, wierszami a polską literaturą Holokaustu. Owo niepodobieństwo jest czymś w rodzaju przeciw-języka (across languages), o którym pisała Butler: łączy, dzieląc, ustanawia nowe pola możliwości ponad oczywistymi podziałami, burzy wyraziste poglądy i różnicuje stanowiska dotąd ze sobą wiązane. Korzystniej bowiem szukać nowej drogi badawczej jako wskazówki dla siebie samej/samego w ogromnej różnorodności, jaką proponują Darwish i Godard. Także różnorodności materiału: film Godarda nie jest po prostu filmem, ale konstelacją wielu obrazów, nie-opowieścią, filmem-nie-do-oglądania. Z kolei poezja Darwisha wydaje się wykazywać tak wysoki stopień ogólności i trudnej symboliki, ahistorycznej i anachronicznej, że trudno niekiedy widzieć w niej antecedensy wypowiedzi o ludobójstwie.

7 Tamże.

8 M. Rothberg: Pamięć wielokierunkowa. Pamiętanie Zagłady w epoce dekolonizacji. Przeł. K. Bojarska. Warszawa 2015, s. 22. 


\section{Teoria kruchości}

Niemal cały świat Naszej muzyki leży w gruzach. Sarajewo przełomu wieków, które odwiedzają goście Europejskiego Kongresu Literackiego, to miasto zniszczonych, wysiedlonych osiedli, zbombardowanych, opustoszałych meczetów, pokawałkowanych mostów. Wiele scen tego filmu dosłownie dzieje się na gruzach i w gruzach: główna bohaterka, Olga Brodsky, czyta pisma Emmanuela Lévinasa w pobliżu zniszczonego mostu w Mostarze; w starym, rozsypującym się meczecie (synagodze?) dwoje Indian inscenizuje sąd nad losem całej indiańskiej społeczności, odgrywając coś w rodzaju „teatru na gruzach”; przyjezdni z okien taksówek podziwiają oprócz gór, otaczających miasto, ruiny, które traktują jak pretekst do snucia refleksji na temat kruchości ludzkiego życia.

Jak przekonuje Mościcki, w dziele Godarda można znaleźć rozległe inspiracje myślą Waltera Benjamina. Z jednej strony dotyczą one metody montowania filmu z fragmentów innych filmów, dzieł sztuki, materiałów archiwalnych. Z drugiej chodzi o nawiązania intertekstualne i intersemiotyczne, oparte na cytowaniu rozmaitych tekstów filozoficznych, literackich i muzycznych, pochodzących nie tylko ze zróżnicowanych źródeł, ale przede wszystkim z odmiennych poziomów estetycznych. Godard zestawia na przykład monumentalne symfonie Valentina Silvestrova z lekką, popularną muzyką filmową. Gra więc cytatami tak, jak zwykli to czynić postmoderniści, choć jego inklinacje do późnego, europejskiego modernizmu wydają się równie ważne. „Struktura filmów Godarda przypomina konstelację fragmentów, w której wewnętrzne napięcia pomiędzy cytatami wyznaczają ramy ich rozumienia [...]. Wielkie dzieło Godarda ma dwóch głównych patronów, których wizja historii, a także metoda jej uprawiania decydują o podstawowych ramach tej opowieści. Są nimi Charles Péguy i Walter Benjamin"”.

Autor Anioła Historii występuje w Naszej muzyce jako filozof gruzów. O jego obecności oprócz zniszczonego miasta przypominają niejasne sekwencje i rozmyte tropy. Jak wystawa fotosów z filmów podejmujących temat wojen i zniszczenia (w tym całkowicie zburzonego w 1865 roku Richmond w stanie Virginia), wśród których znajduje się kilka różnych, spreparowanych ujęć Anioła z gałązka oliwną Hansa Memlinga, nawiązujących do Angelus Novus Paula Klee i komentarza Benjamina: „Gdzie nam ukazuje się łańcuch wydarzeń, on widzi jedną wielką katastrofę, która nieustannie piętrzy gruzy [podkreśl. - M.T.] i ciska mu je pod nogi. Chciałby może się zatrzymać, pobudzić umarłych i złączyć to, co rozbite"10. Gruzy, o których pisze Benjamin, w filmie Godarda służą jednak przede wszystkim podkreśleniu kruchości ludzi (bądź ludzkich zwierząt).

9 P. Mościcki: Godard..., s. 11, 218.

${ }^{10}$ W. Benjamin: Konstelacje. Wybór tekstów. Przeł. A. Lipszyc, A. WoŁkowicz. Kraków 2012, s. 316. 
Są zatem materialną częścią (stroną) teorii wulnerabilności, opracowanej przez Judith Butler w pracy Ramy wojny. Kiedy życie godne jest opłakiwania?!1. Jej podstawę stanowi konflikt palestyńsko-izraelski, dlatego sądzę, że przywoływanie $\mathrm{w}$ tym miejscu kategorii vulnerability akurat za tekstami Butler jest ważnym argumentem dla rozpatrywania Zagłady w kontekście zbrodni kolonialnych, eksponujących aspekt walk bratobójczych, konfliktów sąsiedzkich i sporów o ziemię. I jednocześnie stwarza okazję do zarysowania vulnerability studies poświęconych przede wszystkim Zagładzie.

Podstawą teorii kruchości (vulnerability) jest przekonanie o tym, że wszyscy jednakowo jesteśmy podatni na zranienie (od vulnus - 'rana'). Wulnerabilność wyklucza możliwość zarządzania cierpieniem, ustanawiania jednych ofiar bardziej cierpiącymi od innych i tworzenia hierarchii pokrzywdzonych. Butler twierdzi, że nie można hierarchizować wartości życia. „Uzmysłowienie sobie kruchości innego życia - narażenia na przemoc, tymczasowości wynikającej z uspołecznienia czy wreszcie zbędności - implikuje uświadomienie sobie kruchości każdej żywej istoty i wprowadza zasadę równej podatności na zranienie, która obejmuje wszystkie żyjące byty" ${ }^{\prime 2}$. Jednak podobnie jak Benjamin amerykańska myślicielka poświęca więcej uwagi często zwyciężanym i trwale zwyciężonym. Są nimi między innymi Palestyńczycy uwięzieni w kolonizacyjnym klinczu z Izraelem, próbujący kosztem przeciwnika zmaksymalizować swoją kruchość. Przypomina to każdą inną walkę sąsiadujących ze sobą społeczeństw - najpierw o prawo do bycia bardziej cierpiącą ofiarą, a później do pierwszeństwa w upamiętnianiu „większego" cierpienia. Retoryka konfrontowania krzywd, znana również z historii drugiej wojny światowej oraz umacniania pamięci i tożsamości polskich ofiar oraz narodu kosztem żydowskich i odwrotnie, wymaga przebadania przez pryzmat kategorii kruchości. Jakie skutki może przynieść jej zastosowanie? Przede wszystkim pozwoli odwrócić uwagę od narzucającego się wartościowania, a także zrozumieć, że podstawowe relacje społeczne są relacjami przymusu, a nie wyboru. Kruchość oznacza nie bezzwrotną, niemal średniowieczną pamięć o śmierci, ale życie w uścisku z kimś obcym, niewygodę zatajoną, wypartą dotkliwość, przykrość sąsiadowania z obcym. Relacje Palestyńczyków z Izraelem należą do takich właśnie kruchych i słabych więzów. Podobnie jak relacje Serbów i Bośniaków w Sarajewie. „Współzależność, sąsiadowanie, wreszcie definiującą obie populacje niechcianą bliskość, wprowadzającą w obu przypadkach strach przed wzajemnym zniszczeniem i indukującą postawę destrukcyjności”'13, Butler proponuje podważyć. Najprostszym sposobem jest liczenie tych, którzy zginęli, i stawianie sobie pytania, czy to, że da się ich zliczyć, jest równoznaczne z tym, że się liczą.

${ }^{11}$ J. Butlen: Ramy wojny. Kiedy życie godne jest opłakiwania? Przeł. A. Czarnacka. Warszawa 2011.

12 Tamże, s. 21.

13 Tamże, s. 33. 
Życie palestyńskie przedstawia Butler jako niegodne opłakiwania, niekruche i niewyjątkowe. Postępuje tak, aby zrekonstruować dyskurs polityczny, wedle którego życiem istotniejszym wydaje się życie Izraelczyków (szczególnie w perspektywie konfliktu w Strefie Gazy). „Strona izraelska spełnia ustalone normy życia ludzkiego, to tam życie jest bardziej z życiem, życie istnieje. Tymczasem życie palestyńskie albo jest nie-życiem, albo też cieniem życia, wreszcie - zagrożeniem dla życia, jakie znamy"14.

Konstruowanie pojęć takich jak: „ofiara”, „życie wartościowe” czy „tragedia śmierci", odbywa się w ramach określonej narracji społeczno-politycznej, a ściślej - w ramach wojny i nakłaniania do medialnego uczestnictwa w niej. Dzięki temu odbiorca zostaje „zrekrutowany” do intelektualnego i emocjonalnego udziału w konflikcie. Chcąc osłabić działanie tych konstrukcji i nadszarpnąć zbyt polityczne kategorie, Butler wprowadza pojęcie niepewności. „Czasami udaje nam się zrozumieć, że jesteśmy ze sobą powiązani w tak ścisły sposób, a niepewność może być podstawą twierdzenia o równej wartości każdego życia”"15. Niepewność to także stan, w którym trwa większość bohaterów Naszej muzyki. Główna bohaterka, dwudziestoparoletnia Żydówka o nazwisku Brodsky poszukuje odpowiedzi na pytanie o to, jak jej rodzina uratowała się przed nazistami; jej wuj próbuje odszukać Brodsky, by odwieść ją od samobójstwa; Darwish, Godard i Juan Goytisolo ${ }^{16}$ niepewnie podążają do hotelu Holiday Inn, w którym koją swój strach przed wciąż niebezpiecznym Sarajewem.

Aby jednak dokładnie pojąć, jak Godard rozumie kruchość, należy przyjrzeć się dwóm scenom. W pierwszej z nich podjęty został problem niejednoznaczności takich ról, jak: ofiara, oprawca, przyjaciel, wróg i sąsiad. Francuscy turyści mijają taksówką linię frontu z 1993 roku i zrujnowane bloki mieszkalne. Na ich widok Brodsky płacze, a jej egipski krewny zachowuje kamienną twarz. Oboje cierpią w milczeniu. Komentarz pochodzi od Gilles’a Pecqueux:

Zabijanie ludzi w obronie swych idei nie jest obroną tej idei, lecz zabijaniem ludzi. A kiedy jest po wszystkim, nic nie jest takie, jakie było. Przemoc pozostawia głębokie blizny. To pozostaje w pamięci na zawsze. Wiara w to, że terror niszczy, jest nie do odzyskania. Gdy się widzi przyjaciela, który zwraca się przeciwko tobie, rodzi się poczucie głęboko zakorzenionego horroru. Wtedy przemoc wyznacza linię życia. Ocaleni nie tylko się zmieniają, ale są już innymi ludźmi [podkreśl. - M.T.]. [...] Każdy z nas może stać się zagrożeniem dla innych. Nasze ciała to potencjalna broń ${ }^{17}$.

14 Tamże, s. 37.

15 Tamże, s. 38.

16 Juan Goytisolo Gay (1931-2017) - hiszpański pisarz, autor m.in. Popołudnia trędowatych, Znaków tożsamości i Makabry. W 2014 r. otrzymał Nagrodę Cervantesa. W filmie Godarda gra samego siebie.

17 Nasza muzyka. Reż. i scen. J.-L. GodARD. Francja-Szwajcaria 2004, 0:14:51-0:15:58. 
Kruchość oznacza w tym wypadku ludzką i architektoniczną niewytrzymałość. Domy i pojęcia pękają pod naporem zmian, jakie niosą spory rozsadzające sąsiedzkie wspólnoty.

Wróćmy do łez Olgi. Godard udowadnia, że nie istnieje jedna trauma przypisana trzeciemu pokoleniu (do związków bohaterki z tą kategorią jeszcze powrócę). Zagłada uczyniła jego przedstawicieli istotami na pozór bardziej kruchymi niż inni, ale nie ustanowiła jednego, trwałego modelu kruchości (o czym zresztą przekonuje Butler, powołując się na konflikt w Strefie Gazy). Brodsky staje się w filmie Godarda - jak mówi ambasador Francji w Sarajewie, który uratował jej dziadków przed Holokaustem - nową Hannah Arendt, potomkinią ocalałych, która solidaryzuje się ze wszystkimi przegranymi. Także z tymi, których pokonał jej własny naród.

Spostrzeżenie, że terrorystą może zostać każdy, nabrało znaczenia po 2001 roku i atakach na World Trade Center. W Duchu terroryzmu. Requiem dla Twin Towers Jean Baudrillard postawił tezę, że o niepewności decyduje nasza podatność na zranienie, wynikająca z łatwości, z jaką ludzie przekraczają granice kategorii takich jak sprawca i ofiara ${ }^{18}$. Odpowiada temu totalne spojrzenie na wojnę zaproponowane przez Godarda rozpatrującego jej istotę, począwszy od wypraw krzyżowych, po wojnę w Zatoce Perskiej.

W drugiej interesującej mnie scenie przyglądamy się prowadzonej w hotelu rozmowie Brodsky z Mahmudem Darwishem. Jest ona przedziwna. Darwish mówi w języku arabskim, cytując, a niekiedy wręcz recytując swoją twórczość, z kolei żydowska dziennikarka rozmawia z nim po hebrajsku. W jakiś sposób oboje się rozumieją, choć nie zawsze jest to porozumienie jasne dla widza. W pierwszym pytaniu Brodsky następująco opisuje palestyńskiego poetę: „Mówi Pan, że nie ma już miejsca dla Homera, a jednocześnie jest Pan trojańskim bardem. Kocha Pan zwycięzców. Mówi Pan jak Żyd"19. Rozmowa dotyczy prawdopodobnie eseistycznej książki Darwisha Palestyna jako metafora. Zarówno metafora, jak i metonimia są figurami, za pomocą których pisarz tworzy skondensowaną literaturę przetwarzającą obiekt w znaczenie, ziemię w poezję i poezję w Palestynę ${ }^{20}$. Porównując Izrael do starożytnej Hellady, Darwish nie projektuje jednak prostej analogii. Interesuje go prawo silniejszego do przemocy, zbudowane na doskonałej artystycznie poezji. Grecy podobnie jak Izraelczycy posiadają długą tradycję liryczną, za którą tęskni Palestyna. Skazuje ją to na narrację zwycięzców i wyobrażoną obecność - jako figury - w dramatach Eurypidesa czy eposie Homera. A zatem na tradycję narracji oprawców „użyczających” bądź udzielających ofiarom głosu. Zależność między siłą militarną kraju i jego

${ }_{18}$ J. BaUdrillard: Duch terroryzmu. Requiem dla Twin Towers. Przeł. R. Lis. Warszawa 2005.

19 Nasza muzyka.., 0:21:51-0:21:58.

${ }^{20}$ Por. M. Ghannam, A. El-Zein: Reflecting on the Life and Work of Mahmoud Darwish. “Cirs Brief” 2009, no 3, s. 7. 
poezją, istniejąca także w przypadku kultury niemieckiej i jej złożonych uwikłań w nazizm, prowadzi Darwisha do zaskakującego wniosku: „Czy kraj, który posiada wspaniałych poetów, posiada prawo do zawładnięcia ludźmi?"21. Darwish przedstawia siebie jako poetę trojańskiego, mieszkańca kraju bez tożsamości, głos nieobecnych. Na wszelkie sposoby próbuje jednak nadać niedostatkowi sens. Twierdzi więc, że „Więcej inspiracji i człowieczeństwa jest w porażce niż w zwycięstwie" 22 . Dla poezji zaś odpowiedniejsza wydaje się przegrana; nawet jeśli poeta należy do zwycięzców, powinien okazać solidarność z przegranymi, ponieważ to korzystniejsze dla poezji.

Położenie Palestyny jest zatem paradoksalne. Z jednej strony siła Izraela odbiera jej szanse na wygraną, ale z drugiej sława Izraela przynosi korzyść Palestynie, która w przeciwnej sytuacji nikogo by nie interesowała. Wroga relacja może więc okazać się szczęściem i nieszczęściem. Tak właśnie więzy kruchości opisuje Butler, twierdząc, że nie każde życie nadaje się do opłakiwania; jest takim tylko to życie, które istnieje w sieci społecznych i politycznych uwikłań. W rozmowie z przedstawicielką zwycięzców, która sama za chwilę umrze w akcie solidarności z pokonanymi, Darwish negocjuje nowe ramy kruchości swojego narodu, budując fałszywą genealogię (bard trojański), zapożyczając z poezji żydowskiej retorykę i ustawiając ją w odbitym świetle. Wówczas kruchość staje się kategorią jeszcze bardziej elastyczną niż dotychczas, czerpiącą zysk z własnej słabości, politycznie istotną i pożądaną. A także tworzącą jako rozsadnik pewnych trwałych pojęć grunt dla krytyki syjonizmu, którą przeprowadzają Butler i Godard.

\section{Postsyjonizm}

Nasza muzyka pozwala prześledzić wnioski płynące z zestawienia dyskusji na temat żydowskiej historii i tożsamości z konfliktem palestyńskim. Oddaje więc niemal dosłownie intencje izraelskiego historyka Amnona Raz-Krakotzkina, „który będąc zadeklarowanym krytykiem polityczno-filozoficznego projektu leżącego u podstaw syjonizmu, swoje stanowisko uzasadnia wiernością najważniejszym ideałom żydowskiej tradycji" ${ }^{23}$, w czym wydaje się bliski przekonaniom Butler jako autorki pracy $\mathrm{Na}$ rozdrożu... Postawiona przez filozofkę teza, że „dwunarodowość może prowadzić do rozkładu nacjonalizmu”"24, tłumaczy dobór intelektualnych projektów analizowanych $\mathrm{w}$ Exile and Binationalism:

\footnotetext{
${ }^{21}$ Nasza muzyka..., 0:36:37.

22 Tamże, 0:37:30-0:37:31.

${ }^{23}$ М. Вовако: Islamofobia..., s. 212.

24 J. Butler: Na rozdrożu..., s. 340.
} 
From Gershom Scholem and Hannah Arendt to Edward Said and Mahmoud Darwish ${ }^{25}$. Składa się na nie twórczość autorów takich jak: Darwish, Said czy Azmi Bishara (arabsko-izraelski polityk, krytyk syjonizmu), inspirujących się dziełem niemiecko-żydowskich myślicieli - Theodora Adorno, Ericha Auerbacha i Waltera Benjamina. Diatryba wygłoszona przez Darwisha w obecności Brodsky to rozwinięta parafraza fragmentu szkicu $O$ pojęciu historii:

Tradycja uciśnionych poucza nas, że „stan wyjątkowy”, w którym żyjemy, jest regułą. Musimy wypracować pojęcie historii, które odpowiada tej sytuacji. Wówczas dostrzeżemy, że naszym zadaniem jest wprowadzenie rzeczywistego stanu wyjątkowego; a w ten sposób umocni się nasza pozycja w walce z faszyzmem² ${ }^{26}$.

Takim pojęciem, przenicowanym na drugą stronę historii, jest także postsyjonizm. Świadomość zawiłości podstaw filozoficznych syjonizmu, sprzyjająca uznaniu ich za podatne na krytykę bądź negację, daje sposobność zobaczenia Zagłady w jej uwikłaniu w konflikt palestyński, powinna się jednak skończyć wypracowaniem terminu bądź figury bardziej konkretnej niż postsyjonizm, takiej jak tożsamość hybrydyczna ${ }^{27}$ czy Mizrachim.

W Naszej muzyce tożsamości „myślnikowych”28 jest przynajmniej kilka. O pierwszej wspomina tłumacz zatrudniony przez organizatorów Kongresu, potomek egipskich Żydów z Rosji, syjonistki i więzionego partyzanta, którzy w 1948 roku przedostali się koleją do Jerozolimy, a następnie zamieszkali we Francji. Wciąż tkwi w nim przywiązanie do kultury rosyjskiej, z czym z kolei polemizuje jego siostrzenica Olga, preferująca raczej metafizykę i literaturę francuską (Lévinasa, Juliena Greena). Z krytycznym podejściem do utartych pojęć spotkamy się również w przypadku ambasadora, który w 1943 roku w Lyonie udzielił schronienia parze Żydów. Matka Olgi przyszła na świat na jego strychu. Mimo to nie chce się on zgodzić na rozmowę z dziadkiem dziewczyny, ponieważ, jak twierdzi, nie było w jego zachowaniu niczego nadzwyczajnego, było ono normalne. Także $\mathrm{z}$ tego powodu odmówił kiedyś przyjęcia odznaczenia „Sprawiedliwy wśród Narodów Świata”. Wszystko to czyni ambasadora postacią "myślnikową", połamaną i nieprzyznającą się do dawnego bohaterstwa. Nazwać go można nie-Sprawiedliwym, ponieważ oficjalna polityka kazała mu zaprzeczać głoszonej niegdyś idei oporu. Żegnając się z Olgą, gdy odmawia rozmowy z jej ocalonym dziadkiem, ambasador przytacza następujące zdanie: „W 1943 roku niemiecka katoliczka powiedziała: Marzeniem jednostki jest bycie dwojgiem. Marzeniem państwa jest bycie jednym. Obcięto jej za to głowę" ${ }^{29}$.

${ }^{25}$ Exile and Binationalism: From Gershom Scholem and Hannah Arendt to Edward Said and Mahmoud Darwish. Berlin 2012.

${ }^{26}$ W. Benjamin: Konstelacje..., s. 315.

${ }_{27}$ Por. M. Вовако: Islamofobia..., s. 214.

28 Tamże, s. 215.

${ }^{29}$ Nasza muzyka..., 01:24:28. 
Hybrydyczną tożsamość ma jednak przede wszystkim Olga, na co dzień mieszkająca w Nowym Jorku, Żydówka z Tel Awiwu, która w akcie solidarności z Palestyńczykami umiera w jerozolimskim kinie zastrzelona jako terrorystka. Jej lewicowość, podkreślana przez Godarda na wiele sposobów, w tym za pomocą czerwieni i czerni, którymi otacza się bohaterka, zostaje jednak dotknięta ostrzem krytyki. Śmierć $\mathrm{w}$ pustym kinie $\mathrm{z}$ torbą pełną książek (dziewczyna dała zakładnikom z Izraela wybór, aby umarli razem, ale ostatecznie puściła ich wolno) czyni z Brodsky głosicielkę myśli utopijnej, do której określenie „terrorystka” zupełnie nie pasuje. W filmie, skądinąd skomponowanym na wzór Boskiej komedii Dantego i podzielonym na trzy części odpowiadające piekłu, czyścowi i niebu, widzimy ją, jak prowadzi trzy dłuższe rozmowy: z palestyńskim poetą, politykiem i bratem matki. Właściwie jedynie z Darwishem znajduje porozumienie, chociaż zbudowane ono zostaje na podstawie różnych języków, poziomów wykształcenia, a nawet całkiem innego stopnia otwartości na drugiego (Darwish w istocie referuje swoje pisma, niekiedy czytając, zamiast mówić, co właściwie uniemożliwia mu dialog z Brodsky na poziomie wymiany informacji).

\section{Obrazy ran i wojen}

Obraz wydaje się najważniejszą jednostką w kinie Godarda. Piszą o tym Georges Didi-Huberman, Paweł Mościcki i Barbara Kita ${ }^{30}$. Ale właściwie tylko jeden typ przedstawienia czyni to kino nie-kinem i zaprzecza sensowi jego dalszego istnienia. Odsyła ono do Zagłady, a dokładniej - do braku nagrań z obozów koncentracyjnych. W polemice z Marguerite Duras na temat filmu Shoah Claude’a Lanzmanna reżyser stwierdził, że kino „niczego nie pokazało”31.

Naiwnie sądzono, że Nowa Fala będzie nowym początkiem, rewolucją. Tymczasem było już za późno. Wszystko się skończyło. Koniec zaś nastąpił wtedy, gdy nie sfilmowano obozów koncentracyjnych. W tej właśnie chwili kino całkowicie zawiodło. Sześć milionów osób zostało zagazowanych, głównie Żydzi, i kina przy tym nie było ${ }^{32}$.

A co i w jaki sposób („Pozostało więc tylko sposobem”33) pokazuje na temat Zagłady Godard? Zaledwie kilka nagrań sytuacji, które mogłyby wydarzyć się

${ }^{30}$ B. Kita: Obraz zatrzymany. Praktyka i teoria późnego Godarda. Katowice 2013.

${ }^{31}$ G. Didi-Huberman: Obrazy mimo wszystko. Przeł. M. Kubiak Ho-Chi. Kraków 2012, s. 177.

${ }^{32}$ Tamże, s. 176.

${ }^{33}$ Tamże. 
w getcie warszawskim; masowe groby; zdjęcie Richmond przypominające ruiny getta w Warszawie. To zdecydowanie za mało, by móc zobaczyć w Naszej muzyce autopolemikę. Ale wystarczająco dużo, aby uwierzyć bez reszty w radykalizm reżysera. Znacznie bardziej zastanawiające wydaje się to, dlaczego ambasador odmawia Oldze udzielenia informacji na temat ocalenia jej dziadków, a jedyne przedstawienia, do jakich ją odsyła, to portrety Arendt i Franza Kafki. Czy to oznacza, że Zagładę Godard ukrywa, osłania i traktuje jak tajemnicę? Jak zakazaną reprezentację ${ }^{34}$ ? Nie można jej znaleźć wśród obrazów wielu masakr przypomnianych w części Piekło. Przedstawień Zagłady nie szuka także sama Olga, która sięga raczej po powieści i do poezji (wiedza bardzo młodej bohaterki jest jeszcze wybiórcza).

Darwish w swojej twórczości proponuje zupełnie inne rozwiązanie. O wojnie opowiada za pomocą skomplikowanych i zarazem ogólnych, obrazowych symboli, z których rana pozostaje, zaraz obok ziemi, najważniejszym tematem:

Lecz miasto stoi na szczycie nowej rany w wybuchu burzy.

Co mówi wiatr?

- My, wiatr, wywracamy okręty i planety,

namioty i trony.

Co mówi wiatr?

- My, wiatr,

Roznosimy hańbę Twoich niebiańskich ud... ${ }^{35}$.

Raną nazywa poeta miasto również w Pieśni miłości na krzyżu. Rana jest or-

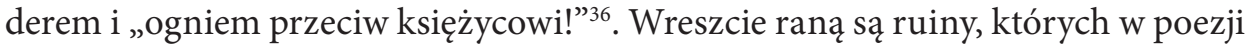
Darwisha jest równie dużo, co gruzów u Godarda. Odrealniona, metaforyczna fraza jego tekstów nadaje się przede wszystkim do tworzenia teorii: na temat kruchości, wygnania, śmierci. Próbę teoretyzowania wierszem podjął Darwish w utworze Nie ma już dla nas miejsca na ziemi. Roztacza w nim przerażającą wizję kurczącej się, znikającej przestrzeni życia dla Palestyńczyków, poza którą czeka ich śmierć. Dwukrotnie pojawia się w niej ciało. Po raz pierwszy, gdy stłoczeni na skrawku ziemi ludzie odejmują „członki ciała” jak zbędny bagaż, byle tylko się zmieścić. Po raz drugi, kiedy pojawia się zapowiedź okaleczenia pieśni, „Żeby nasze ciało mogło ją dokończyć"37.

Zagłada narodu palestyńskiego została ukazana za pomocą retoryki, którą wypracowano dla opowieści o Zagładzie Żydów. Kurczenie się przestrzeni do

${ }^{34}$ Por. J.-L. Nancy: Zakazana reprezentacja. Przeł. A. Dziadek. „Teksty Drugie” 2004, nr 5 .

${ }^{35}$ M. Darwish: To jej obraz... A on zabił się z miłości... W: Pieśni gniewu i miłości..., s. 193.

${ }^{36}$ M. Darwish: Nie śpij. W: Pieśni gniewu i miłości..., s. 173.

${ }^{37}$ M. Darwish: Nie ma już dla nas miejsca na ziemi. W: Pieśni gniewu i miłości..., s. 177. 
życia i stłoczenie ludzi w gettach to niewypowiedziany punkt wyjścia dla Darwisha, który jednak kończy tę chóralną narrację biblijnym, pomyślanym jako przymierze (między kim a kim?) credo: „tutaj z naszej krwi wyrośnie drzewo oliwne"38. Jego tekst ma charakter zapowiedzi, a nie świadectwa. Projektuje możliwą przyszłość na kanwie znanej już historii w taki sposób, aby odpowiedziała ona na pytanie, jak uczynić niemożliwą do przeżycia przestrzeń przestrzenią znośną. Usuwanie z poezji obrazów drastycznych nie oznacza usuwania ich w ogóle, ale przesunięcie poza słowa ku obrazom. Pisze o tym Darwish w wierszu, w którym toczy wyimaginowany, pośmiertny dialog z Saidem:

Nie opisuj słowem ran, które można uchwycić na kliszy.

I krzycz, byś mógł usłyszeć siebie,

i krzycz, aby mieć pewność, że żyjesz,

i że nie umarłeś, i że życie na tej ziemi

jest wciąż możliwe ${ }^{39}$.

„Chciałam zobaczyć miejsce, gdzie pojednanie wydaje się możliwe” - tłumaczy swój pobyt w Sarajewie Olga ${ }^{40}$. Brak miejsca do życia nie jest równoznaczny z brakiem życia. Oznacza istnienie chwiejące się w posadach swojej kruchości, upchane, pozbawione prawa do wolności indywidualnej, bezimienne, ale wciąż jeszcze możliwe. Czy krzyk, o którym pisze Darwish, nie jest sprzeciwem wobec tradycji odbierania głosu uciśnionym? Butler powiada: „Nakba w pewnym sensie nigdy się nie kończy, nigdy nie przechodzi do historii”, i pyta: „czy słowa poezji mogą się przyczynić do otwarcia przyszłości przekraczającej horyzont katastrofy?"41.

Godard daje widzowi możliwość myślenia o przyszłości w ostatniej części filmu zatytułowanej Niebo, gdzie wciąż obowiązują ludzkie ograniczenia, ale bohaterom udaje się je ominąć lub przekroczyć. Jednocześnie reżyser pozostaje bardzo krytyczny wobec przedstawicieli francuskiej lewicy, która z niezwykłą lekkością wyrzuca z siebie komentarze na temat ran i przemocy, pijąc i bawiąc się w okrytym żałobą Sarajewie. Jednak to jej narracja - oparta na słowach ambasadora i samego Godarda, odgrywającego siebie w sposób niezwykle sarkastyczny - jest słyszalna. Właśnie dlatego, że w Sarajewie znaleźli się Francuzi, chcemy oglądać ten film i słuchać intelektualnych komentarzy oraz muzyki. Głos Olgi pozostaje niestety ledwo słyszalny. Godard, któremu podarowano jej materiał filmowy, nie potrafi sobie przypomnieć dziennikarki, gdy dowiaduje się o zamachu w kinie. Darwish w swoim wykładzie o arabskiej Troi pozostaje

38 Tamże.

39 M. Darwish: Edward Said. A Contrapuntal Reading. Trans. M. Anis. "Cultural Critique" 2007, nr 3, s. 175-182, cyt. za: J. Butlen: Na rozdrożu..., s. 364.

40 Nasza muzyka..., 01:48:12.

${ }^{41}$ J. Butler: Na rozdrożu..., s. 373. 
jeszcze mniej sprawczy, jeszcze bardziej bezsilny. Szczególnie, kiedy przypomni się, że nie za sprawą własnej poezji, ale jej powiązań z Zagładą i europejskim filmem, krytykującym myślenie Europejczyków o muzułmanach, stał się tematem tego artykułu.

Taka polityka lektury może okazać się zdradliwa. W sytuacji odżywających dawnych konfliktów europejskich powinniśmy wzmóc czujność wobec gestów kolonizujących pamięć i, jak radzi Butler, wyzbyć się skłonności do zamykania pojęć w ich tradycyjnych formułach. Sprawcy i ofiary, terrorystka czy węzeł palestyński to tylko pierwsze $\mathrm{z}$ nich i nie najważniejsze. O wiele ryzykowniejsze wydają się próby rewaloryzacji rozumienia samej Zagłady. Język - twierdzi filozofka w Walczacych słowach... - jest zwykle zanurzony w jakiejś traumie, co wcale nie czyni go przedmiotem teorii traumy. Przeciwnie, rysująca się między traumą a wulnerabilnością różnica, obejmująca między innymi podatność na zranienie za pomocą mowy, może jednocześnie mieć wartość otwierającą, sprawczą i przyszłościową. „A jednak owe [raz na zawsze dane niezależnie od nas - M.T.] terminy, nigdy przez nas naprawdę niewybierane, stwarzają okazję dla czegoś, co wciąż można nazwać sprawczością - dla powtórzenia źródłowego podporządkowania $\mathrm{w}$ innym celu, którego przyszłość pozostaje częściowo otwarta" ${ }^{\prime 2}$.

Nie przypadkiem akcja Naszej muzyki toczy się w Sarajewie. Jest to miejsce, które samo nie mając jeszcze głosu, przemawia głosem narracji o innych ludobójstwach, konfliktach politycznych, religijnych czy rasowych. Dzięki temu widać pogłębiający się rozpad świata: na ludzi kruchych, reprezentowanych przez takie figury jak Mizrachim, mieszaniec czy hybryda, i cyniczny Zachód, okopany w systemach zapewniających mu kapitał, błyskotliwe formułki i bezpieczeństwo. Dla studiów nad Zagładą jest to układ korzystny: nie tylko bowiem zapewnia im polityczne znaczenie, ale także pozwala rozważać Holokaust poza polityką, w kontekście takich pojęć, jak wulnerabilność czy zmienność statusu ocalonych, które każą pytać, co dzieje się między ludźmi po powrocie na dawne pozycje i zapomnieniu o historii.

\section{Bibliografia}

Baudrillard J.: Duch terroryzmu. Requiem dla Twin Towers. Przeł. R. Lis. Warszawa 2005.

Benjamin W.: Konstelacje. Wybór tekstów. Przeł. A. Lipszyc, A. WoŁkowicz. Kraków 2012.

42 J. Butler: Walczace słowa. Mowa nienawiści i polityka performatywu. Przeł. A. Ostolski. Warszawa 2010, s. 50. 
Вовако M.: Islamofobia jako technologia władzy. Studium z antropologii politycznej. Kraków 2017.

Butler J.: Fiction and Solicitude. Ethics and the Conditions for Survival. In: Probing the Ethics of Holocaust Culture. Eds. C. Fogu, W. Kansteiner, T. Presner. Cambridge, Massachusetts-London 2016, s. 373-388.

Butler J.: Na rozdrożu. Żydowskość i krytyka syjonizmu. Przeł. M. Filipczuk. Warszawa 2014.

Butler J.: Ramy wojny. Kiedy życie godne jest opłakiwania? Przeł. A. Czarnacka. Warszawa 2011.

Butler J.: Walczace słowa. Mowa nienawiści i polityka performatywu. Przeł. A. OstolSKI. Warszawa 2010.

DARWISH M.: To jej obraz... A on zabił się z miłości...; Pieśń miłości na krzyżu; Nie śpij; Nie ma już dla nas miejsca na ziemi. W: Pieśni gniewu i miłości. Wybór arabskiej poezji współczesnej. Oprac., przeł., wstęp K. SKarżyńsKa-BocheńsKa. Warszawa 1990.

Didi-Huberman G.: Obrazy mimo wszystko. Przeł. M. Kubiak Ho-Chi. Kraków 2012. Exile and Binationalism: From Gershom Scholem and Hannah Arendt to Edward Said and Mahmoud Darwish. Berlin 2012.

Ghannam M., El-Zein A.: Reflecting on the Life and Work of Mahmoud Darwish. "Cirs Brief" 2009, no 3.

Kita B.: Obraz zatrzymany. Praktyka i teoria późnego Godarda. Katowice 2013.

Mościcki P.: Godard. Pasaże. Kraków-Warszawa 2010.

Nancy J.-L.: Zakazana reprezentacja. Przeł. A. Dziadek. „Teksty Drugie” 2004, nr 5.

Rothberg M.: Pamięć wielokierunkowa. Pamiętanie Zagłady w epoce dekolonizacji. Przeł. K. BoJArska. Warszawa 2015.

Marta Tomczok

"My friend from Haifa said that when he dreamed, he dreamed not about the enemy, but about himself" Studies on the Palestinian-Israeli Conflict as a Challenge for the Holocaust Studies

Summary

In the article, the author endeavours to describe the advantages of juxtaposing studies on the Palestinian-Israeli conflict with the Holocaust studies. Arguments for it are found in works in sociology and philosophy of prejudice and ethnic conflicts (Monika Bobako), reflections on memory and decolonisation (Michael Rothberg), and - especially - those on dual nationality as a philosophical issue (Judith Butler). However, the author primarily focuses on further developing Butler's intriguing theory of vulnerability and applying it to fragility as a political, architectural, and existential problem. In order to do so, the author discusses the poetry of Mahmud Darwish (hardly present in Poland) and the film Notre musique by Jean-Luc Godard.

Key words: vulnerability, Jewishness, Zionism, Darwish, Godard 